PRZEGLĄD NAUK HISTORYCZNYCH 2017, R. XVI, NR 1

http://dx.doi.org/10.18778/1644-857X.16.01.08

DROBNE PRACE I MATERIAEY

Siergiej Paweowicz Karpow

Moskiewski Uniwersytet Państwowy im. M.W. Łomonosowa*

\title{
Superbia Genueńczyków w połowie XIV wieku w oczach bizantyńskich i weneckich historyków i kronikarzy ${ }^{1}$
}

K

onfrontacja Wenecji i Genui w XIV w. była jednym z ważniejszych czynników w historii globalnej tego okresu i w istottemu zajęła się wyjaśnieniem przyczyn tych zmagań, wskazując na ich ekonomiczne i polityczne tło $^{2}$. W mniejszym stopniu znana jest

*Wydział Historyczny, Katedra Historii Średniowiecza, e-mail: spkarp1204@, yandex.ru.

1 Artykuł przygotowany w ramach realizacji projektu RNF (14-28-00213).

${ }^{2}$ M. Volkov, O soperničestve Venecii s Genuej v XIV v., „Zapiski Odiesskavo Obščestva Istorii i Drievnostiej" 1869, t. IV, s. 151-236; W. Heyd, Histoire du commerce du Levant au moyen âge, t. I, Leipzig 1885, s. 502-509; t. II, Leipzig 1886, s. 187-291; A. S o r b e11i, La lotta tra Genova e Venezia per il predominio del Mediterraneo, [w:] Memorie della R. Accademia delle scienze dell' Istituto di Bologna. Classe di scienze morali, serie I, Sezione di scienze storico-filologiche, t. V, Bologna 1910-1911, s. 87-157; M. Brunetti, Contributo alla storia delle relazioni Veneto-Genovesi dal 1348 al 1350, [w:] Miscellanea di Storia Veneta, ed. per cura della R. Deputazione Veneta di Storia Patria, Ser. III, t. IX, Venezia 1916, s. 1-160; E.Č. Skržin skaja, Petrarka o genuezcach na Levante, „Vizantijskij vremiennik" 1949, t. II, s. 245-266; e a d e m, Barbaro $i$ Kontarini o Rossii, Leningrad 1971, s. 34-38; G. Brătia nu, La Mer Noire. Des origines à la conquête ottomane, München 1968, s. 269-273; F. Surdich, Genova e Venezia fra Tre e Quattrocento, Genova 1970; C. Kyrris, John Cantacuzens and the Genoese 1321-1348, [w:] Miscellanea Storica Ligure, t. III, Milano 1963, s. 9-48; id e m, John Cantacuzenus, the Genoese, the Venetians and the Catalans (1348-1354), [w:] Atti del I Congresso Storico Liguria-Catalogna, Bordighera 1974, s. 188-210; B.Z. Ke d a r, Merchants in crisis. Genoese and Venetian men of affairs and the fourteenthcentury depression, New Haven-London 1976; I.P. Medvedv, Dogovor Vizantii i Genui ot 6 maja 1352 g., „Vizantijskij vremiennik” 1977, t. XXXVIII, s. 161-172; 
ocena tego, co działo się w ówczesnej lub chronologicznie blisko związanej $z$ tymi wydarzeniami historiografii, reprezentowanej przez różne szkoły narodowe i różne kierunki, przez wzajemne oddziaływanie idei i ocen, pochwał i oskarżeń, pasji i rozmów. Wydawałoby się, że istnieja dwa bieguny tej literatury, które należą do różnych tradycji, odmienne pod względem językowym, konfesyjnym i ideowym: składaja się na nią bardzo bogate i dawne bizantyńskie piśmiennictwo, i nie tak dawne, ale bardzo patriotyczne weneckie kronikarstwo. Należą do niej interesujące i często niepozbawione piękna elokwencji zbiory dokumentów weneckich zgromadzeń. W dziwny sposób nieco na uboczu dla tego okresu znajduje się genueńskie kronikarstwo, to dużo późniejsze i - jak się wydaje - mniej zorientowane na to, co można umownie nazwać „interesem państwowym”. Celem artykułu jest ukazanie ocen genueńskiej polityki we współczesnych dla tego wieku i bliskich mu dziełach historyków i kronikarzy.

Zainteresowanie Genueńczyków Morzem Czarnym, ich walka o wyłączność na przywileje i chęć umocnienia się na obu brzegach tego akwenu, zarówno północnym, jak i południowym, przypisane zostały im przez bizantyńskich autorów jeszcze w latach osiemdziesiątych XIII w. w liście patriarchy Grzegorza $z$ Cyrpu do protosebastosa i protowestiariusza Teodora Muzalona ${ }^{3}$. Na początku XIV w. wyraźnie daje się zauważyć takie podejście u Jerzego Pachymeresa, który opisuje konflikt genueńsko-trapezuncki z 1304 r. $^{4}$

M. Balard, La Mer Noire et la Romanie Génoise (XIIIe-XVe ss.), Leningrad 1989, nr 2 i 5; S.. Papacostea, La Mer Noire carrefour des grandes routes intercontinentales 1204-1453, Bucuressti 2006, s. 132-201; O. Cris tea, Rivalitatea venețiano-genoveza in Marea Neagra: campaniile lui Giustiniano Giustiniani (1323, 1328), „Revista Istorică” 2004, t. XV, nr 1-2, s. 89-106; id e m, Genoa's Struggle for Hegemony in the Black Sea (Thirteenth-Fourteenth Centuries), vol. II, Historical Yearbook, Bucuressti 2005, s. 117-132; ide m, The Venetian „Four Seasons" in the Black Sea: the Chronicle of an unsuccessful Hegemony, „Revue roumaine d'histoire" 2007, t. XLVI, no. 1-4, s. 5-23; i d e m, Veneția şi Marea Neagră în secolele XIII-XIV. Contribuții la studiul orientale venețiene, Brăila 2004; S. O rig o n e, Guerra e società nel Mar Nero. Il confronto tra Genovesi e Veneziani, [w:] Proceedings of the 22 $2^{\text {nd }}$ International Congress of Byzantine Studies. Sofia, 22-27 August 2011, vol. I (Plenary Papers), Sofia 2011, s. 431-439.

${ }^{3}$ Por. A.E. Laiou, Monopoly and privilege: the Byzantine reaction to the Genoese presence in the Black Sea, [w:] Oriente e Occidente tra medioevo ed età moderna. Studi in onore di Geo Pistarino a cura di Laura Balletto, t. II, Aqui Terme 1997, s. 675-686.

${ }^{4}$ Georges Pachymérès, Relations historiques, ed. A. Failler, t. IV (Livres XXIII), Paris 1999, s. 493.12-495.14; A.E. Lai ou, On political geography: the Black Sea of Pachymeres, [w:] The making of Byzantine History. Studies dedicated to 
Charakteryzując postępowanie Genueńczyków, Pachymeres pisze o wrodzonej im $\varphi$ povíua, czyli „pysze”, superbia ${ }^{5}$. To słowo stanie się niemal stereotypowym określeniem wskazującym na ambicje Liguryjczyków w Lewancie.

W roku 1343 znajdujący się w Tanie (Azaku, Azowie) wenecki patrycjusz Andreoli Civrano został znieważony („dostał policzek”) przez Tatara, prawdopodobnie urzędnika chana. Nie mogąc znieść upokorzenia, Civrano zabił sprawcę. Konflikt, który wyrósł z obyczajowej kłótni, przerodził się w starcie wszystkich „Łacinników” $z$ mieszkańcami Ordy. Włosi zostali zmuszeni do ucieczki z Tany, pozostawiajac tam znaczne nieruchomości, a jednocześnie zabierając ze sobą coś $z$ tatarskich dóbr. Genueńczycy i część Wenecjan schronili się w Kaffie, inni powrócili do ojczyzny dzięki zakotwiczonym tam statkom weneckiej floty handlowej. Kłótnia doprowadziła do interwencji chana, do długotrwałego sporu morskich republik $z$ „imperatorem” Dżanibekiem, które zawarły między soba tymczasowa „unię”. Nastapiła blokada morska nadbrzeży Ordy przez Włochów i zakończone niepowodzeniem, ale ciężkie oblężenie Kaffy przez Tatarów, która stała się schronieniem i centrum handlu zarówno dla Genueńczyków, jak i dla Wenecjan ${ }^{6}$. Unia okazała się krucha. Włosi, którzy powstrzymywali się od pływania po Morzu Azowskim, zaczęli szukać możliwości zawarcia $z$ chanem oddzielnego pokoju i ostatecznie tego dokonali: najpierw Genueńczycy - wiosna 1374 r., a 26 grudnia 1347 r. także Wenecjanie ${ }^{7}$. Ci ostatni, uciskani kontrolą konkurentów w Kaffie, starali się powrócić do zagospodarowanej

D.M. Nicol, eds R. Beaton, Ch. Roueché, London 1993, s. 104-105; S.P. Karpov, Istorija Trapezundskoj imperii, St. Petersburg 2007, s. 278-281.

5 Georges Pachymérès, op. cit., s. 495.2. Wydawca i tłumacz dzieła Pachymeresa A. Failler przekłada to słowo jako „arrogance”, co znaczy „zarozumiałość”, „wyniosłość" (ibidem, s. 494).

${ }^{6}$ Więcej szczegółów por. S.P. Karpov, Krizis serediny XIV v.: nedoocenennyj povorot?, [w:] Vizantija meždu Zapadom i Vostokom. Opyt ictoričeskoj charakteristiki, otv. red. akad. G.G. Litavrin, St. Petersburg 1999, s. 220-238; id e m, Krizis Tany 1343 g. v svete novych istočnikov, "Vizantijskij vremiennik” 1994, t. LV (LXXX), č. 1, s. 121-126; idem, Génois et Byzantins face à la Crise de Tana de 1343 d'après les documents d'archives inédits, „Byzantinische Forschungen” 1996, Bd. XXII, s. 33-51.

${ }^{7}$ R. Morozzo Della Rocca, Notizie da Caffa, [w:] Studi in onore di A. Fanfani, vol. III (Medioevo), Milano 1962, s. 275; A.P. Grigorev, V.P. Grigo re v, Jarlyk Džanibeka ot $1347 \mathrm{~g}$. Venecianskimi kupcami Azova (Rekonstrukcija soderžanija), [w:] Istoriografija i istočnikovedenie istorii stran Azii $i$ Afriki, St. Petersburg 1995, vyp. XV, s. 36-83; A.P. Grigorev, Kollekcija zolotoordynskich dokumentov XIV veka iz Venecii, St. Petersburg 2002, s. 78-121. 
już przez nich Tany, a Genueńczycy - nie dopuścić do ulokowania się ich w większej bliskości miejsc eksportowych dla wschodnich towarów i handlu niewolnikami. W rezultacie, jeszcze przed zawarciem umowy Wenecji $z$ chanem, Genueńczycy z Kaffy wszelkimi sposobami zaczęli ograniczać wenecki handel w tym mieście, zaaresztowali wenecki statek i jego ładunek (o czym władze weneckie informowały posła Genui, prosząc go, by wywarł presję na administrację Kaffy ${ }^{8}$ ), a następnie zaczęli blokować cieśninę Kreczu, aresztować weneckich kupców i przejmować ich towary ${ }^{9}$, powołując się na wyłączność praw do handlu w regionie Morza Czarnego, przewidzianym w traktacie $z$ Nimfeon zawartym $z$ Michałem VIII Paleologiem w 1261 r. Niekiedy uważa się, że podstawą genueńskich roszczeń do monopolu handlowego w tym regionie były tylko artykuły o wyłączności ich praw handlowych wedle umowy $z$ Nimfeon ${ }^{10}$. Jednak ani Bizantyjczycy, ani Wenecjanie nie przyjmuja tego argumentu.

Wenecjanie nie mogli się zgodzić $z$ pretensjami przeciwników, powołujac się na swoje prawa i na dawniejsze umowy $z$ cesarzami bizantyńskimi. W 1350 r. rozpoczęła się długa i krwawa wojna morskich gigantów, do której zostało wciagnięte i okazało się pokonane również Bizancjum ${ }^{11}$. Umowa mediolańska z 1355 r. między Genua a Wenecją była zasadniczo tymczasowym kompromisem, który nie wskazał niepodważalnego zwycięzcy, ale nasiliła dawny spór o wolności handlu czy też o prawach do monopolu jednej ze stron. Blokada żeglugi rywali w Tanie stała się dla Genueńczyków kluczowa i obsesyjna idea ich polityki, tak jak później dla Wenecjan zawładnięcie wyspa Tenedos na przedpolach Konstantynopola ${ }^{12}$. Zresztą

8 Venezia-Senato. Deliberazioni miste. Registro XXIV (1347-1349), a cura di E. Orlando, Venezia 2007, nr 336 - 10/IX 1347; nr 361 - 4/X 1347.

9 Archivio di Stato di Venezia, Senato Secreta, B, f. $7 r-19 /$ V 1348.

10 O. Cristea, Genoa's Struggle..., s. 123; id e m, The Venetian „Four Seasons” in the Black Sea: the Chronicle of an unsuccessful Hegemony, „Revue roumaine d'histoire" 2007, t. XLVI, no. 1-4, s. 11.

${ }^{11}$ E.Č. Skržinskaja, Genuezcy $w$ Konstantynopole $w$ XIV w., „Vizantijskij vremiennik" 1947, t. I, s. 215-234; eade m, Petrarka o genuezcach...; F. Thirie t, La Romanie Vénitienne au moyen âge, Paris 1959 (repr.: 1975), s. 168-178; M. Balard, À propos de la bataille du Bosphore. L'expédition de Paganino Doria à Constantinople (1351-1352), Travaux et Mémoires, Paris 1970, t. IV, s. 431-469 [= M. Balard, La Mer Noire et la Romanie Génoise (XIIIe-XVe siècles), London 1989, N 2]; idem, La Romanie Génoise (XIIe-début du XVe siècle), t. I, RomaGenova 1978, s. 78-85; D. Nicol, Byzantium and Venice. A study in diplomatic and cultural relations, Cambridge 1988, s. 264-295.

${ }^{12}$ S.. Papacostea, "Quod non iretur ad Tanam". Un aspect fondamental de la politique Génoise dans la Mer Noire au XIVe siècle, „Revue des études sud-est 
genueńskie władze także widziały początek konfliktu w wydarzeniach z 1343 r., podkreślając okrucieństwa Wenecjan w Tanie, które doprowadziły do złupienia i zabójstw tamtejszych chrześcijan ${ }^{13}$.

W latach pięćdziesiątych-sześćdziesiątych XIV w., kiedy dopiero co zakończyła się wojna, niemal jednocześnie bizantyńscy i weneccy historycy zaczęli oceniać przyczyny i konsekwencje tej wielkiej konfrontacji. W pismach greckich autorów, $z$ całą różnorodnościa opinii, przewijają się dwie stałe myśli: związek wojny $z$ handlowymi interesami morskich republik i zwiąek genezy konfliktu $z$ kryzysem w Tanie z 1343 r. Sa także różnice: dla bizantyńskich historyków najistotniejszy jest związek wydarzeń $z$ gorzkim losem cesarstwa Romejów, które stało się bezradną ofiarą w starciu morskich republik, nadmierne przywileje, które otrzymali Genueńczycy z Kaffy od chana Ordy - „hegemona Scytów”, szybki wzrost opanowanych przez nich terytoriów, wzmożenie się pychy „Łacinników”, którzy zaczęli odnosić się z pogardą do miejscowych Tatarów, „Scytów” zgodnie ze słowami Gregorasa. Dla niego nie ma także znaczenia miejsce pojawienia się iskry nienawiści - czy była to dobrze ufortyfikowana Kaffa, o której pisze wcześniej, czy bardziej oddalona Tany, która dobrze zna, ale w tym miejscu swej relacji nawet nie wymienia jej nazwy. Walka przeniosła się na blanki Kaffy, która przetrzymała oblężenie genueńskiej staży przedniej ${ }^{14}$. Dla Gregorasa jasne jest, że łacińska pycha była niebezpieczna dla całego helleńskiego świata. Przejawiało się to i w naruszeniu przez nich umów z Bizantyńczykami, i w tym, że zamek Galata (Pera) kontroluje sam Konstantynopol, i w morskich zwycięstwach Liguryjczyków nad bizantyńską flotą ${ }^{15}$.

européennes" 1979, t. XVII, no. 2, s. 201-217; idem, De la guerre du Bosphore à la guerre de Ténédos: rivalité commerciales et alignements politiques dans le SudEst de l'Europe dans la seconde moitié du XIVe siècle, [w:] Coloniser au moyen âge, sous la direction de M. Balard et A. Ducellier, Paris 1995, s. 341-347, 350-352; id e m, La Mer Noire..., s. 132-156; O. Cri st ea, Veneția şi Marea Neagră în secolele XIII-XIV. Contribuții la studiul orientale venețiene, Brăila 2004, s. 117-153; R. Hrys zko, $Z$ Genui nad Morze Czarne. $Z$ kart genueńskiej obecności gospodarczej na pótnocno-zachodnich wybrzeżach Morza Czarnego u schyłku średniowiecza, Kraków 2004, s. 32-35.

13 Tola Pasquale. Codex diplomaticus Sardiniae, t. I, [w:] Historiae Patriae Monumenta, t. X, Torino 1861, s. 756-757 (a. 1353): „ut scitur, et publicum et notorium est pro maleficiis Venetorum Ianuenses et omnes Christicole qui in illo loco Tane tunc temporis se invenerunt, fuerunt mortui et spoliati...".

${ }^{14}$ Nicephori Gregorae Byzantina historia, a cura L. Schopeni, t. II, Bonnae 1830, s. 683-686.

15 Nicephori Gregorae Historiae Byzantinae libri postremi, ed. I. Bekker, Bonnae 1855, s. 41. 
Właśnie dlatego Gregoras bezpośrednio (jakkolwiek bez realnych podstaw) wiąże wystąpienie Greków przeciw Genueńczykom w Trapezuncie w latach 1348-1349 z konfliktem z 1343 r. na północnym wybrzeżu Morza Czarnego ${ }^{16}$. Opisując poczatek wojny, Gregoras lojalniej odnosi się do Wenecjan: sa oni ofiarami tego, że Genueńczycy, wbrew ich oczekiwaniom, przeszkodzili statkom Republiki Św. Marka doświadczonym w pływaniu ku północnym brzegom Morza Czarnego, Meotis (Morza Azowskiego) i ujścia Donu ${ }^{17}$. Marszcząc brwi, Genueńczycy zamierzali ustanowić hegemonię nad całą żegluga po Morzu Czarnym, ich wzrok był pełen nieugiętej dumy,

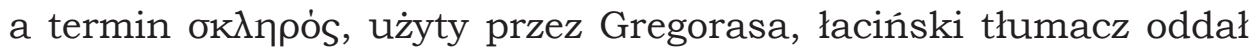
właśnie jako superbia ${ }^{18}$. Zresztą Gregoras, dobrze znający historię Genui i wskazujący na pragnienie Genueńczyków, aby zapanować nad morzami od Azowskiego aż do słupów Heraklesa, nie bez ironii pisze o następstwach tej arogancji - w końcu sama republika w 1353 r. znalazła się pod rządami obcego władcy (zarządcy Mediolanu Giovanniego Viscontiego) ${ }^{19}$.

Jan VI Kantakuzen, w odróżnieniu od Gregorasa, winą za incydent w Tanie $z 1343$ r. i zabójstwo Tatara obarcza wprost nie „Łacinników” w ogóle, a konkretnie: Wenecjan. Początek genueńsko-weneckiej wojny wiąże jednakże $z$ tym, że Genueńczycy pragnęli, by ani bizantyńscy (romejscy), ani weneccy kupcy, ani ich własne statki nie pływały do Tany, pod pretekstem, by znów $z$ tej przyczyny nie wikłać się w wojnę z Tatarami („Scytami”), a w rzeczywistości: aby zwiększyć dochód $z$ handlu dla wszystkich emporii Kaffie, która znajdowała się pod kontrolą Genueńczyków. Wenecjanie jednakże zupełnie nie przyjmowali możliwości przerwania żeglugi do Tany i nie chcieli słyszeć o zgodzie; powiadali, że nic nie przeszkodzi im w pływaniu tam, gdzie tylko im się podoba. Genueńczycy w odpowiedzi zaczęli stosować przemoc, napadać na weneckich kupców, przejmować ich statki handlowe, czym doprowadzili do wojny ${ }^{20}$. W mniej wyraźnej formie Kantakuzen podaje jednak wszystkie te

16 Nicephori Gregorae Byzantina historia..., s. 687, 3-9. Por. S.P. Ka r pov, Istoria Trapezundskoj..., s. 287-288.

17 Nicephori Gregorae Historiae Byzantinae libri postremi..., s. 41-42.

18 Ibidem, s. 41, 17.

19 Ibidem, s. 194. Por. A.E. Laiou, Italy and Italians in the Political Geography of the Byzantines (14 $4^{\text {th }}$ Century), "Dumbarton Oaks Papers” 1995, t. XLIX, s. 95-96.

${ }^{20}$ Ioannis Cantacuzeni historiarum libri IV, ed. J. Schopen, vol. III, Bonnae 1832, s. 191.19-193.10. 
same pojęcia o roszczeniach Genueńczyków do wyłączności w handlu czarnomorskim.

Najwcześniejsze świadectwa weneckiego kronikarstwa o przyczynach rozpętanej w $1350 \mathrm{r}$. wojny, o ile nam wiadomo, znajduja się $\mathrm{w}$ dwóch tekstach $\mathrm{z}$ lat sześćdziesiątych XIV w.: w anonimowej kronice weneckiej (Venetiarum Historia), przypisywanej Petro Giustinianiemu, i w kronice Enrico Dandola. Venetiarum Historia odnotowuje chęć Genueńczyków „przywłaszczenia sobie” (apropriare [powinno być chyba appropiare - M.C.]) Morza Czarnego i zablokowania weneckiej żeglugi do Tany, co wywołało ich silny opór i konflikt zbrojny ${ }^{21}$. W swym dziele, w jednym rzędzie $z$ tymi argumentami, Enrico Dandolo pokazuje, że Genueńczycy popadli w wielka pychę („se elevono in molta superbia”). Dalej rozwija argumenty strony genueńskiej, że Morze Czarne zostało przez nich „oswobodzone” („franchado per loro”) w walce $z$ „Saracenami i Tatarami" i to Genueńczycy ponieśli przez Wenecjan wielkie szkody $z$ powodu incydentu w Tanie w 1343 r. Dlatego domagali się, by Wenecjanie nie pływali po Morzu Czarnym, ale kierowali się tylko do Kaffy, gdzie mogliby prowadzić swój handel. Ze względu na niechęć Wenecjan do podporządkowania się temu ograniczeniu Genueńczycy zaczęli „przeszkadzać” weneckiej żegludze (do Tany) ${ }^{22}$. W odpowiedzi wenecki doża Andrea Dandolo, jak wspomina jeden z kronikarzy z końca XIV w. Rafael Carezini, głosił tezę o potrzebie ochrony wolności morza za wszelką cenę („libertatem maris summo studio summisque viribus conservare") ${ }^{23}$.

Dokładniejsze motywy konfliktu podaje piszacy w latach dwudziestych XV w. sekretarz Republiki Weneckiej i kreteński urzędnik Lorenzo Monacci. Podobnie jak bizantyńscy historycy bezpośrednio wiąże początek sporu $z$ wydarzeniami w Tanie w 1343 r., ale zdecydowanie zaprzecza, jakoby Wenecjanie ponosili winę za pierwszy

${ }^{21}$ Venetiarum Historia vulgo Petro Iustiniani filio adiudicata, a cura di R. Cessi e F. Benuato, Venezia 1964, s. 231. Na jego temat por. SS.V. Marin, Some considerations regarding the anonymous Venetiarum Historia (14 $4^{\text {th }}$ Century), vol. VII, Historical Yearbook 2010, s. 177-194. Ten sam argument o genueńskim pragnieniu bezprawnego przywłaszczenia sobie Morza Czarnego („volentibus Mare Maius sibi solis indebite vendicare”) wybrzmiewa u XIV-wiecznego kronikarza Raffaino Caresiniego; Raphayni de Caresinis, Chronica AA.1343-1388, a cura di Pastorello Ester, [w:] Rerum Italicarum scriptores, ed. L. Muratori [dalej: RIS], t. XII/II, fasc. 1-2, Bologna 1923, s. 6.

22 Cronica di Venexia detta di Enrico Dandolo, origini - 1362, a cura di Roberto Pesce, presentazione di Angela Caracciolo Aricò, Venezia 2010, s. 127.

${ }^{23}$ Raphayni de Caresinis, op. cit., s. 6. 
impuls konfliktu - zabójstwo Tatara w Tanie, uważając tego ostatniego za sprawcę, a sam epizod za prywatny, ale nie za publiczna sprawę („privatam iniuriam non debere trahi ad contumeliam rei publicae"). Głównym powodem konfliktu według niego była restrykcyjna polityka Genueńczyków, uważających Morze Czarne, a tym bardziej Azowskie za swoje, i ich chęć kontrolowania całego tamtejszego handlu i niedopuszczania doń cudzoziemców bez właściwego pozwolenia. Za motyw dla Genueńczyków posłużyło to, że rzekomo to oni oczyścili morze $z$ piratów i Turków. Monacci przeciwstawił tej ekskluzywności wenecka politykę, która także doprowadziła do oczyszczenia Adriatyku z piratów i ataków Maurów i Saracenów, ale uczyniła to dla dobra wszystkich chrześcijan. Autor przywodzi ciekawszy argument: kluczowe punkty na morzu - Perę i Kaffę - Genueńczycy uzyskali za pomoca oszustwa na obcej ziemi, podczas gdy Wenecjanie, władcy czwartej części i jeszcze połowy czwartej części całego imperium Romajów, władają tą częścią nie tyle siła, ile prawem i rozumem, potwierdzając od czasu do czasu wieczysty pokój dzięki porozumieniom z cesarzami Greków. Po raz kolejny pojawia się ten sam motyw: pycha Genueńczyków rozgorzała ponad miare („conflavit elata supra modum superbia Januensium" ${ }^{24}$. W ten sam sposób konflikt objaśniaja, wskazując na pychę Genueńczyków, inni kronikarze XV w.: Antonio Morozi$\mathrm{ni}^{25}$, Pseudo-Gianncarlo ${ }^{26}$, Anonim XV w. (Pseudo-Niccolo Trevizan $)^{27}$, Giorgio Dolfin ${ }^{28}$, Marino Sanuto Młodszy ${ }^{29}$.

Interesujaca zmiana $\mathrm{w}$ weneckiej historiografii następuje od końca XV w do początków XVII w. Marcantonio Sabiellico (oficjalnych kronikarz od 1486 r.) już nie pisze o superbia Genueńczyków jako o głównym powodzie konfliktu, ale do określenia historii po-

${ }^{24}$ Laurentii de Monacis veneti Cretae cancellarii Chronicon de rebus Venetiis ab u.c. ad annum 1354, sive ad conjuracionem ducis Faledro. Accedit ejusdem Laurentii Carmen de Carolo II, Rege Hungariae. Omnia ex mss. editisque codicibus eruit, recensuit, praefationibus illustravit Flaminius Cornelius, Venetiis 1758, s. 207-208.

25 „Siando zenovexi in gran cholmo zia vegnudi, e masimamente loro trafegando in le parte del Mar Mazior, posa i diti se leva in molta soperbia"; Il Codice Morosini. Il mondo visto da Venezia (1094-1433), edizione critica, introduzione, indice e altri apparati di A. Nanetti, t. I, Spoleto 2010, s. 65-66.

${ }^{26}$ Cod. Marc. It., VII, 50 (9275), f. 298v-299r („la ellata superbia di Zenoesi”).

27 Cod. Marc. It., VII, 519 (8438).

28 Dolfin Gi orgi o, Cronicha dela nobil cità de Venetia et dela sua provintia et destretto. Origini - 1458, a cura di A. Caracciolo Aricò, introduzione di A. Caracciolo Aricò, trascrizione e note di Chiara Frison, t. II, Venezia 2009, s. 28 („Zenoexi se levò molto in superbia").

${ }^{29}$ Sanuto Marino, Vitae ducum Venetorum, RIS, t. XXII, Milan 1733, s. 621. 
czątku wojny używa delikatniejszego terminu: iniuria - niesprawiedliwość ${ }^{30}$. Tym pojęciem posługuje się już Marino Sanuto Młodszy ok. 1490 r., ale sassiaduje on $z$ wcześniejszym - superbia. Kolejny kronikarz, piszacy w latach trzydziestych XVI w. Giovanni Giaccomo Caroldo, kiedy mówi o początku konfliktu i pragnieniu Wenecjan, by zatrzymać jego rozwój w drodze negocjacji, używa kluczowych terminów: discordia, differenze („niezgoda”) ${ }^{31}$. Andrea Navagero, tworzacy w tym samym czasie, zatrzymuje się zasadniczo na prawnej stronie genueńskich pretensji: według niego dażyli oni do wyłącznego prawa żeglugi po tych morzach („soli pretendevano la giurisdizione del navigare in quei mari") $)^{32}$. Późniejsi kronikarze, jak np. Giulio Faroldo (ok. 1577), także będą wiązać genezę konfliktu $z$ wydarzeniami w Tanie w 1343 r. Faroldo napisze nawet, wyraźnie przekręcając rzeczywistość, że Genueńczycy, chcąc przenieść handel do Kaffy, z zemsty spalili Tanę („havevan arsa la Tana, per vendetta del danno ricevuto in el 1343") ${ }^{33}$.

Oficjalny wenecki historiograf od 1631 r., senator Paolo Morosini, do pewnego stopnia zgadzając się $z$ wytworami wcześniejszej tradycji, nie odwołując się do pychy Genueńczyków, zwrócił po prostu uwage na następujące okoliczności. Genueńczycy władali kilkoma posiadłościami na Morzu Czarnym, a po opanowaniu Pery zaczęli mieć $z$ tego wielkie korzyści. Wciąż było im jednak mało i zapragnęli odebrać Wenecjanom to, co im pozostało; zdecydowali się zatem wyrzucić ich stamtąd i pozbawić możliwości żeglowania do tych miejsc. Kiedy weneckie statki znajdowały się w porcie Kaffy, Genueńczycy niespodziewanie na nie napadli, w następstwie czego wybuchła wojna ${ }^{34}$.

Genueńskie kronikarstwo, w przeciwieństwie do weneckiego, uchyla się od podania ideowych przyczyn konfliktu między dwiema republikami. Giorgio Stella (zm. 1420 r.), a za nim Agostino Giustiniani (1470-1536) oraz późniejsi kronikarze i historycy, opis

${ }^{30}$ Sabellico Marcantonio, Degl'Istorici delle cose Veneziane $i$ quali hanno scritto per pubblico decreto, t. I, Istorie veneziane latinamente scritte da M.A. Sabellico, parte 1-2, Venezia 1718, s. 302.

${ }^{31}$ Caroldo Giovanni Giacomo, Istorii Venețiene, vol. III (De la alegerea dogelui Andrea Dandolo la moartea dogelui Giovanni Delfino [1343-1361), ediție îngrijită de S..V. Marin, Bucureşti 2010, s. 35-36.

${ }_{32}$ Naugerii Andreae patritii Veneti Historia Veneta, RIS, t. XXIII, Milan 1733, s. 1034.

${ }^{33}$ Faroldo Iulio, prete Cremonese, Annali Veneti, Venezia 1577, s. 218.

${ }^{34}$ Morosini Paolo, Historia della città e Republica di Venetia, Venetia 1637, s. 245 . 
konfliktu zaczynaja od informacji o napadzie 35 weneckich galer na 14 handlowych genueńskich galer w pobliżu Chios ${ }^{35}$. Paolo Interiano (poł. XVI w.) tylko przelotnie stwierdza, że Wenecjanie rzekomo pragnęli całkowitego pozbawienia Genueńczyków władzy nad Lewantem („privar totalmente Genovesi del dominio di Levante”) ${ }^{36}$. Jak wskazuje jednak później sam autor, celem genueńskich kapitanów było zawładnięcie morzem i sława Republiki („per l'Imperio del mare e per la gloria della loro Republica") ${ }^{37}$, co bynajmniej nie jest sprzeczne $z$ zarzutami, o których słyszeliśmy od ich weneckich przeciwników. Dopiero w latach osiemdziesiątych XVI w. utalentowany genueński historyk Oberto Foglietta (1518-1581) wprost wskazał na to, że w genueńskich annałach w żaden sposób nie podaje się („nulla tradatur”) przyczyny wojny i dlatego jest zmuszony zwrócić się ku innym źródłom, przede wszystkim ku wielu weneckim pisarzom ${ }^{38}$.

Nie mniej interesująca jest reakcja na to, co się zdarzyło, a co znalazło odzwierciedlenie $\mathrm{w}$ historiografii innych włoskich miast. Podamy kilka charakterystycznych przykładów. Boloński kronikarz ogólnie informuje o starciu w Tanie, zarówno Wenecjan, jak i Genueńczyków z Tatarami i ich ucieczce do genueńskiej Kaffy. Obie republiki zawarły wtedy umowę, przewidująca powstrzymanie się od odwiedzania Tany. W ten sposób mieli nadzieję na pokonanie Tatarów w Tanie albo zmuszenie ich do sprowadzania towarów do Wenecji lub Genui. Jednakże Wenecjanie, $z$ naruszeniem zasad umowy, bez porozumienia $z$ Genueńczykami rozpoczęli rozmowy $z$ chanem, zawarli $z$ nim umowę i zaczęli odwiedzać Tanę i inne podległe mu miasta. Zauważmy przy okazji, że w rzeczywistości pierwszą umowę z Dżanibekiem zawarli Genueńczycy. W odpowiedzi na porozumienie Wenecjan z chanem Genueńczycy, jak kontynuuje kronikarz, uzbroili statki, zaczęli napadać na Wenecjan i ich znieważać. Strony, szukając kompromisu, zwrócili się do papieża i rzekomo zgodziły się $z$ tym, że morze powinno należeć do wszystkich. W 1350 r. Wenecjanie posłali do Tany trzy galery, a Genueńczycy, „nie mniej pełni pychy” („non meno superbi”), atakowali Wenecjan

${ }^{35}$ P. Stella, (RIS, XVII, P.1091) Giustiniani Agostino, Annali della Repubblica di Genova, t. II, Genova 1854, s. 91; Interiano Paolo, Ristretto delle Historie Genovesi, Lucca 1551, s. 109r.

${ }^{36}$ Interiano Paolo, op. cit., s. 109v.

37 Ibidem, s. $118 \mathrm{v}$.

${ }^{38}$ Foglietta Oberto, Uberti Folietae Patricii Genuensis Historiae Genuensium Libri XII, Genuae 1585, s. 138v. 
i zajmowali ich statki. Rozpoczęła się wojna ${ }^{39}$. Jak widzimy, mówiąc o pysze Genueńczyków, kronikarz zrównuje ją $z$ wenecką i wini raczej Wenecjan niż Genueńczyków za naruszenie umów. Przy czym jego teza o tym, że strony porozumiały się za pośrednictwem papieża odnośnie do „otwartości morza”, jest tak iluzoryczna, jak przypisywanie im nadziei, że mieszkańcy Ordy sami będa przypływać po towary do włoskich miast. Takie albo zbliżone do tych oceny podaje także florencki kronikarz, dodając, że zawarcie przez Wenecjan umowy $z$ chanem wywołało zawiść („livor”) Genueńczyków. Stroniąc od innych ocen, kronikarz odnotowuje schwytanie przez Genueńczyków trzech weneckich statków, zazwyczaj pływających do Tany, i wydarzenia $z$ początku wojny ${ }^{40}$.

Florencki kronikarz Matteo Villani (zm. 1363 r.) wskazuje na zazdrość, rywalizację między miastami („invidia di stato”) jako główna przyczynę wojny, które miały także swoje źródło w wydarzeniach w Tanie w 1343 r. Uważa jednakże, że konflikt z Dżanibekiem rozpoczęli Genueńczycy, kiedy spalili Tanę, przez co przerwali żegluge do tego miejsca. Skupili oni cały handel przyprawami we własnym porcie - w Kaffie i dazżyli do tego, by także Wenecjanie tam handlowali i korzystali z przywilejów, immunitetów i wolności. Taka polityka miała być, wedle zamysłu Genueńczyków, jak pisał Villali, dobra dla całego chrześcijaństwa. Wenecjanie próbowali pływać tam, dokąd im się żywnie podobało, a kłótnia („briga”) Genueńczyków $z$ chanem rzekomo ich nie dotyczyła ${ }^{41}$. Villali, jak się zdaje, nie zna przyczyny kłótni Wenecjan $z$ Tatarami w Tanie albo ja ukrywa i tym samym jakby zdejmuje $z$ nich odpowiedzialność za rozpoczęcie konfliktu, ale zarazem nie pisze o roszczeniach Genueńczyków, by dominować na Morzu Czarnym.

Termin superbia, pycha, początkowo jest kluczowym pojęciem zarówno dla Wenecjan, jak i (jego grecki odpowiednik) dla autorów bizantyńskich. Teksty bizantyńskich i włoskich pisarzy są niezależne od siebie i nie mają zapożyczeń tekstologicznych albo zbieżności, oprócz wspólnego podejścia i ocen. Jednocześnie następuje wyraźne złagodzenie inwektywy w kronikarstwie od końca XV do XVI w.

${ }^{39}$ Corpus Chronicorum Bononensium, a cura di A. Sorbelli, RIS, NS, t. XVIII, parte 1, fasc. 9-11, 1927, s. 612-614.

40 Chronicon Estense cum additamentis usque ad annum 1478, a cura G. Bertoni e P.V. Vicini, RIS, t. XV, parte 3, fasc. 1-3, Bologna 1937, s. 172, 178-179.

${ }^{41}$ Villani Matthaei ejusque filii Philippi Historia ab anno MCCCXLVIII ad annum MCCCLXIV (Historie di Matteo Villani cittadino Florentino, che continua quello di Giovanni suo fratello), RIS, t. XIV, Milano 1729, s. 81-82. 
Wymaga to osobnego wyjaśnienia $i$, wydaje się, że polega ono na zmianie ekonomicznych priorytetów. Tureckie zdobycze i częściowe „zamknięcie” przez Osmanów Morza Czarnego złagodziły rywalizację dawnych konkurentów i pozbawiły znaczenia tezy o hegemonii i dominacji w tym regionie.

Tym niemniej wyraźne pragnienie Genui w XIII-XIV w. zmonopolizowania handlu znalazło odzwierciedlenie $w$ odpowiedzi na nie w literaturze, w umocnieniu w niej stereotypu superbii Genueńczyków. Tutaj ukazujemy swego rodzaj uniwersalizm, zrodzony nie przez polityczne ambicje władców czy przez papieskie próby utwierdzenia supremacji, jak w latach walki cesarstwa i papiestwa na Zachodzie, a wykute w walce o wyłączność monopolu handlowego. Umocnił się nowy typ uniwersalizmu, handlowy, nastawiony na wykluczenie i zdławienie przeciwników, czy to Bizantyńczyków, czy też innych „Łacinników”. Nowe rozumienie uniwersalności miało nie polityczne, ale ekonomiczne konotacje. Nazwę nadali bizantyńscy autorzy: "thalassokracja” - panowanie nad morzami. Bizancjum utraciło ja, Wenecja uzyskała w wyniku IV krucjaty, ale nie utrzymała, a Genua walczyła o nia, prawie jej się udało, ale się nadwerężyła. Wszystko to, bezpośrednio lub pośrednio, ale $\mathrm{w}$ równej mierze zostało odzwierciedlone $\mathrm{w}$ bizantyńskiej i włoskiej historiografii, w jednakowy sposób rozumiejącej, w ostateczności, daremność i iluzoryczność pyszałkowatych ambicji „władców mórz”.

Z języka rosyjskiego przełożył

Marcin CyRULSKI

\section{Bibliografia}

\section{$\dot{Z}_{\text {RÓDEA ARCHIWALNE }}$}

Archivio di Stato di Venezia

Senato Secreta, B, f. 7r - 19/V 1348.

\section{$\dot{Z}_{\text {RÓDEA DRUKOWANE }}$}

Caroldo Giovanni Giacomo, Istorii Venețiene, vol. III (De la alegerea dogelui Andrea Dandolo la moartea dogelui Giovanni Delfino [1343-1361]), ediție îngrijită de Ş.V. Marin, Bucureşti 2010. 
Chronicon Estense cum additamentis usque ad annum 1478, a cura G. Bertoni e P.V. Vicini, [w:] Rerum Italicarum scriptores, ed. L. Muratori, t. XV, parte 3, fasc. 1-3, Bologna 1937.

Corpus Chronicorum Bononensium, a cura di A. Sorbelli, [w:] Rerum Italicarum scriptores, ed. L. Muratori, t. XVIII, parte 1, fasc. 9-11, Bologna 1927.

Cronica di Venexia detta di Enrico Dandolo, origini-1362, a cura di Roberto Pesce, presentazione di Angela Caracciolo Aricò, Venezia 2010.

Dolfin Giorgio, Cronicha dela nobil cità de Venetia et dela sua provintia et destretto. Origini-1458, a cura di A. Caracciolo Aricò, introduzione di A. Caracciolo Aricò, trascrizione e note di Chiara Frison, t. II, Venezia 2009.

Faroldo Iulio, prete Cremonese, Annali Veneti, Venezia 1577.

Foglietta Oberto, Uberti Folietae Patricii Genuensis Historiae Genuensium Libri XII, Genuae 1585.

Georges Pachymérès, Relations historiques, ed. A. Failler, t. IV (Livres X-XIII), Paris 1999.

Giustiniani Agostino, Annali della Repubblica di Genova, t. II, Genova 1854.

Heyd W., Histoire du commerce du Levant au moyen âge, t. I-II, Leipzig 1885-1886.

Il Codice Morosini. Il mondo visto da Venezia (1094-1433), edizione critica, introduzione, indice e altri apparati di A. Nanetti, t. I, Spoleto 2010.

Interiano Paolo, Ristretto delle Historie Genovesi, Lucca 1551.

Ioannis Cantacuzeni historiarum libri IV, ed. J. Schopen, vol. III, Bonnae 1832.

Laurentii de Monacis veneti Cretae cancellarii Chronicon de rebus Venetiis ab u.c. ad annum 1354, sive ad conjuracionem ducis Faledro. Accedit ejusdem Laurentii Carmen de Carolo II, Rege Hungariae. Omnia ex mss. editisque codicibus eruit, recensuit, praefationibus illustravit Flaminius Cornelius, Venetiis 1758.

Morosini Paolo, Historia della città e Republica di Venetia, Venetia 1637.

Naugerii Andreae patritii Veneti Historia Veneta, [w:] Rerum Italicarum scriptores, ed. L. Muratori, t. XXIII, Milan 1733.

Nicephori Gregorae Byzantina historia, a cura L. Schopeni, t. II, Bonnae 1830.

Nicephori Gregorae Historiae Byzantinae libri postremi, ed. I. Bekker, Bonnae 1855.

Raphayni de Caresinis, Chronica AA. 1343-1388, a cura di Pastorello Ester, [w:] Rerum Italicarum scriptores, ed. L. Muratori, t. XII/II, fasc. 1-2 , Bologna 1923.

Sabellico Marcantonio, Degl'Istorici delle cose Veneziane i quali hanno scritto per pubblico decreto, t. I, Istorie veneziane latinamente scritte da M.A. Sabellico, parte 1-2, Venezia 1718.

Sanuto Marino, Vitae ducum Venetorum, [w:] Rerum Italicarum scriptores, ed. L. Muratori, t. XXII, Milan 1733.

Tola Pasquale. Codex diplomaticus Sardiniae, t. I, [w:] Historiae Patriae Monumenta, t. X, Torino 1861.

Villani Matthaei ejusque filii Philippi Historia ab anno MCCCXLVIII ad annum MCCCLXIV (Historie di Matteo Villani cittadino Florentino, che continua quello di Giovanni suo fratello), [w:] Rerum Italicarum scriptores, ed. L. Muratori, t. XIV, Milano 1729. 


\section{OpRacowania}

Balard M., À propos de la bataille du Bosphore. L'expédition de Paganino Doria à Constantinople (1351-1352), Travaux et Mémoires, Paris 1970, t. IV [= M. Balard, La Mer Noire et la Romanie Génoise (XIIIe-XVe siècles), London 1989, N 2].

Balard M., La Mer Noire et la Romanie Génoise (XIIIe-XVe ss.), Leningrad 1989.

Balard M., La Romanie Génoise (XIIe-début du XVe siècle), t. I, Roma-Genova 1978.

Brătianu G., La Mer Noire. Des origines à la conquête ottomane, München 1968.

Brunetti M., Contributo alla storia delle relazioni Veneto-Genovesi dal 1348 al 1350 , [w:] Miscellanea di Storia Veneta, ed. per cura della R. Deputazione Veneta di Storia Patria, Ser. III, t. IX, Venezia 1916, s. 1-160.

Cristea O., Genoa's Struggle for Hegemony in the Black Sea (Thirteenth-Fourteenth Centuries), vol. II, Historical Yearbook, Bucureşti 2005.

Cristea O., Rivalitatea venețiano-genoveza in Marea Neagra: campaniile lui Giustiniano Giustiniani (1323, 1328), „Revista Istorică” 2004, t. XV, nr 1-2, s. 89-106.

Cristea O., The Venetian „Four Seasons” in the Black Sea: the Chronicle of an unsuccessful Hegemony, "Revue roumaine d'histoire” 2007, t. XLVI, no. 1-4, s. 5-23.

Cristea O., Veneția şi Marea Neagră în secolele XIII-XIV. Contribuții la studiul orientale venețiene, Brăila 2004.

Grigorev A.P., Kollekcija zolotoordynskich dokumentov XIV veka iz Venecii, St. Petersburg 2002.

Grigorev A.P., Grigorev V.P., Jarlyk Džanibeka ot 1347 g. Venecianskimi kupcami Azova (Rekonstrukcija soderžanija), [w:] Istoriografija $i$ istočnikovedenie istorii stran Azii i Afriki, St. Petersburg 1995, vyp. XV, s. 36-83.

Hryszko R., Z Genui nad Morze Czarne. Z kart genueńskiej obecności gospodarczej na pótnocno-zachodnich wybrzeżach Morza Czarnego u schyłku średniowiecza, Kraków 2004.

Karpov S.P., Génois et Byzantins face à la Crise de Tana de 1343 d'après les documents d'archives inédits, „Byzantinische Forschungen” 1996, Bd. XXII, s. $33-51$.

Karpov S.P., Istorija Trapezundskoj imperii, St. Petersburg 2007.

Karpov S.P., Krizis serediny XIV v.: nedoocenennyj povorot?, [w:] Vizantija meždu Zapadom i Vostokom. Opyt ictoričeskoj charakteristiki, otv. red. akad. G.G. Litavrin, St. Petersburg 1999, s. 220-238.

Karpov S.P., Krizis Tany 1343 g. v svete novych istočnikov, „Vizantijskij vremiennik" 1994, t. LV (LXXX), č. 1, s. 121-126.

Kedar B.Z., Merchants in crisis. Genoese and Venetian men of affairs and the fourteenth-century depression, New Haven-London 1976.

Kyrris C., John Cantacuzens and the Genoese 1321-1348, [w:] Miscellanea Storica Ligure, t. III, Milano 1963, s. 9-48.

Laiou A.E., Italy and Italians in the Political Geography of the Byzantines $\left(14^{\text {th }}\right.$ Century), „Dumbarton Oaks Papers” 1995, t. XLIX. 
Laiou A.E., Monopoly and privilege: the Byzantine reaction to the Genoese presence in the Black Sea, [w:] Oriente e Occidente tra medioevo ed età moderna. Studi in onore di Geo Pistarino a cura di Laura Balletto, t. II, Aqui Terme 1997, s. 675-686.

Laiou A.E., On political geography: the Black Sea of Pachymeres, [w:] The making of Byzantine History. Studies dedicated to D.M. Nicol, eds R. Beaton, Ch. Roueché, London 1993.

Marin S..V., Some considerations regarding the anonymous Venetiarum Historia (14th Century), vol. VII, Historical Yearbook 2010.

Medvedv I.P., Dogovor Vizantii i Genui ot 6 maja 1352 g., „Vizantijskij vremiennik” 1977, t. XXXVIII, s. 161-172.

Morozzo Della Rocca R., Notizie da Caffa, [w:] Studi in onore di A. Fanfani, vol. III (Medioevo), Milano 1962.

Nicol D., Byzantium and Venice. A study in diplomatic and cultural relations, Cambridge 1988.

Origone S., Guerra e società nel Mar Nero. Il confronto tra Genovesi e Veneziani, [w:] Proceedings of the 22 ${ }^{\text {nd }}$ International Congress of Byzantine Studies. Sofia, 22-27 August 2011, vol. I (Plenary Papers), Sofia 2011, s. 431-439.

Papacostea S.., "Quod non iretur ad Tanam”. Un aspect fondamental de la politique Génoise dans la Mer Noire au XIVe siècle, „Revue des études sud-est européennes" 1979, t. XVII, no. 2, s. 201-217.

Papacostea Ş., De la guerre du Bosphore à la guerre de Ténédos: rivalité commerciales et alignements politiques dans le Sud-Est de l'Europe dans la seconde moitié du XIVe siècle, [w:] Coloniser au moyen âge, sous la direction de M. Balard et A. Ducellier, Paris 1995.

Papacostea S.., La Mer Noire carrefour des grandes routes intercontinentales 1204 1453, Bucureşti 2006.

Skržinskaja E.Č., Barbaro i Kontarini o Rossii, Leningrad 1971.

Skržinskaja E.Č., Genuezcy $w$ Konstantynopole $w$ XIV w., „Vizantijskij vremiennik" 1947, t. I, s. 215-234.

Skržinskaja E.Č., Petrarka o genuezcach na Levante, „Vizantijskij vremiennik” 1949, t. II, s. 245-266.

Sorbelli A., La lotta tra Genova e Venezia per il predominio del Mediterraneo, [w:] Memorie della R. Accademia delle scienze dell' Istituto di Bologna. Classe di scienze morali, serie I, Sezione di scienze storico-filologiche, t. V, Bologna 1910-1911, s. 87-157.

Surdich F., Genova e Venezia fra Tre e Quattrocento, Genova 1970.

Surdich F., John Cantacuzenus, the Genoese, the Venetians and the Catalans (13481354), [w:] Atti del I Congresso Storico Liguria-Catalogna, Bordighera 1974, s. $188-210$.

Thiriet F., La Romanie Vénitienne au moyen âge, Paris 1959 (repr.: 1975).

Venetiarum Historia vulgo Petro Iustiniani filio adiudicata, a cura di R. Cessi e F. Benuato, Venezia 1964. 
Venezia - Senato. Deliberazioni miste. Registro XXIV (1347-1349), a cura di E. Orlando, Venezia 2007, nr 336 - 10/IX 1347; nr 361 - 4/X 1347.

Volkov M., O soperničestve Venecii s Genuej v XIV v., „Zapiski Odiesskavo Obščestva Istorii i Drievnostiej” 1869, t. IV, s. 151-236.

Siergiej PawŁowicz Karpow

\section{Superbia of the Genoese in the mid-14 ${ }^{\text {th }}$ century in the eyes of Byzantine and Venetian historians and chroniclers}

\footnotetext{
$\mathrm{T}_{\mathrm{c}}^{\mathrm{h}}$ anch he article treats the approach of the Byzantine and Italian historians and chroniclers of the $14^{\text {th }}-17^{\text {th }}$ centuries to the problem of claims of the Republic of Genoa to establish its monopoly in trade and navigation in the Black Sea area. It seemed to be one of the causes of the war between Venice and Genoa in 1350-1355 that dramatically affected the Byzantine Empire. The author studies terminology of various writers defining political aspirations of the Genoese Republic.
}

Keywords: Genoa, Venice, Byzantine, Black Sea, Tana, Crimea, historiography, chronicle, politics, ideology. 